\title{
Law Analysis Towards Judicial Review of Interfaith Marriage
}

\author{
Rosdalina Bukido ${ }^{1}$, Edi Gunawan ${ }^{1}$, Rahman Mantu ${ }^{1}$ \\ \{rosdalina.bukido@iain-manado.ac.id $\left.{ }^{1}\right\}$ \\ IAIN Manado ${ }^{1}$
}

\begin{abstract}
Interfaith marriage is still debatable in Indonesia's family law. The interfaith marriage regulation is assumed to reduce the right to choose a life partners in a different religions. Therefore, the judicial review towards the Article 2 paragraph (1) Act No 1 of 1974 on Marriage to Indonesia's Constitutional Court. Indonesia's Constitutional Court issues a decision Number 68/PUU-XII/2014 against the judicial review submitted by applicants. This article focuses on law analysis towards the judicial review of interfaith marriage. The litigants feel unfair and restrictive rights. Constitutional argumentation about the applicant is in Article 16 DUHAM on Human Rights. On the other perception, Indonesia's Constitutional Court Consideration refusing judicial review is a theology aspect, because marriage is not only anthropocentrism and the impact of marriage law status.
\end{abstract}

Keywords: Marriage, Interfaith, Indonesia's Constitutional Court, Human Rights, Judicial Review

\section{Introduction}

Indonesia is a legal state having regulation on marriage, that is Act No 1 of 1974 on Marriage. Article 2 paragraph (1) states: "that marriage is valid "if done according to the law of religion and belief of each party". The regulation does not allow interfaith marriage.

Indonesians who want to do the interfaith marriage will choose another different country because the regulation about interfaith marriage is unclear, so that people feel have no law force.

Most of people who want to do interfaith marriage are difficult to register their marriage in the Registration Office for Population Affairs. The office cannot register the interfaith marriage because no religions and acts allow that kind of marriage.

There is the assumption that the Act No 1 of 1974 on Marriage breaks the religion, marriage, legal certainty, and equality rights. Thus, judicial review is filed for the act. The judicial review is related to the freedom, no boundaries to the race, skin color, sex, language, religion, political choice, nation, or society. Based on Human Rights, marriage is from the agreement of two parties. The interfaith marriage of Convention Decision about Civil Right held by United Nation stated that no intervention towards people and their family to choose their life partner.

However, the interfaith marriage makes other problems, such as problem in household, inheritance of husband, wife and children. Hence, it becomes controversial until the interfaith marriage filling the judicial review to Indonesia's Constitutional Court about the Act No 1 of 
1974 on Marriage. However, Indonesia's Constitutional Court against all filed judicial review through Constitutional Court Decision No 68/PUU-XII/2014.

Regarding to the passage above, the writer did the law analysis towards judicial review filed to the Indonesia's Constitutional Court, the basic question in this paper is "Is judicial review filed to the Indonesia's Constitutional Court a part of demand justice, equality in law and how the law argumentation established by the litigants.

\section{Methods}

The type of this research is library research, namely qualitative research with descriptive analytic descriptive analytic studies in this research intended to explain and clearly describe the reasons used by the Constitutional Court in deciding judicial review in terms of the status of interfaith marriages.

The approach used in this study is: The normative juridical approach method, because the researcher will analyze the judicial review decision of the Constitutional Court related to interfaith marriages, and what considerations are used by judges in deciding interfaith marriages.

\section{Results And Discussion}

\subsection{The Interfaith Marriage in the Indonesian Law}

The interdict of interfaith marriage was applied before Indonesian independence [1] People in any places of the country have animism faith followed by Hindu and Buddha that entered the country. The marriage is based on the religion and the customs, and it tends to interdict the different religion or group of marriage.

Indonesia has many tribes, the tribes members who want to marry with a member of different tribe, they must be a member of the tribe by wedding ceremony. If they do not become a member, they are assumed to out from the tribe or less perfect of their membership.

Hindu is not allowed the marriage between man and woman form different caste [2]. While Buddha is a bit looser, however it tends to be banned. Islam came to Indonesia, and forbid the interfaith marriage, it is mentioned in Al Qur'an, although there is still different interpretation about the interfaith marriage in Islam.

Catholic which is brought by Portuguese is banned the interfaith marriage and judged unofficially [3]. Moreover, the Netherland coming in the end of 16th century and conquered Portuguese also spread religion, Protestant. When Netherland come to Indonesia, Islam had developed. Law developing in society was Islam law, thus Netherland always faced it.

In the colonization period, the Netherland tried to change the customary law with the law from Netherland and to separate the customary and Islam law. There was separation between European (Christian) and natives (Islam or non-Christian). The religion was an indicator of those two groups. The Christians was equally with the European, even though they were Chinese, Indian, Arabian, or even Indonesian, while non-Christians were equally with native, even though they were European.

In the Netherland law, the regulation of the interfaith marriage was named intermarriage in Dutch, Regeling op de gemengde religions (GHR). The regulation was empowered by the kingdom declaration on December, 29 ${ }^{\text {th }}, 1986$ No.23, staatsblad 1989 No 158. In this regulation was mentioned that: ".....the origin, and or legal status, cannot be a backstop of marriage”. Article 2 issued: “ .....because of marriage, thus the woman (lost her original legal 
status and gets a new one) gets her husband legal status and follow it". In 1901, there were additional policy, that difference can not be an obstacle of intermarriage (article 7 paragraph 2). At that time, different religion was not a backstop for someone wanted to do the interfaith marriage. It was based on article 7 paragraph 2 of GHR that different religion, nation, or origin was not an obstacle of intermarriage.

Alysa cited Sudargo Gautama that there are five intermarriage types regulated by GHR (found in the colonization period and after independence was lost/cleared), such as [4]:

1. International marriage, is a marriage between two people in different nation, although probably they are in compliance with the same law.

2. Inter religion marriage, is a marriage between Indonesian natives but they are in compliance with the customary law.

3. Interplace marriage, is a marriage between people in different servant status(between Governor and civil)

4. Intergroup marriage, is a marriage between two people who are in compliance with the different law, and

5. Interfaith marriage, is a marriage between two people in different religion.

Based on those types, a European muslim man who will have married with a moslem native woman must still in compliance with GHR, married in Civil Registry Office and cannot be in front of Muslim leader because their marriage is an intergroup marriage. The man is in compliance with the Europe law and the woman is with the customary law. As a Christian woman who wants to marry with a moslem man with Islam law and in front of the Muslim leader, the marriage is not accepted and should marry in Civil Registry Office by using GHR (because two parties are in abide to different law) or they use HOCI (because one party is Christian).

\subsection{Interfaith Marriage After Independence}

In the beginning of Indonesian independence, muslims prosecute to make new marriage act which can protect Muslims to marry the non moslem men. Moreover, it was submitted by woman organization.

Before formulating the marriage act, government succeed to endorse the marriage registration, talaq, and reconciliation for Muslims, that was the Act no 22 of 1946. On August 1950, the government officiated a committee to collect and arrange the main ideas (regulation) about married, talaq, and reconciliation. This committee contained the representative of many groups, religions, and the bachelors of law.

In 1952, legislative general of marriage had been formulated and in 1954 legislative general of Islam marriage had been also formulated. The two legislative generals were discussed in the House of Representatives in 1958-1959, however the act was not formulated. It was caused by the unstable of political condition, the competition among parties under UUDS 1959 and President decree on June 1st 1959 which stated that back to the 1945 Constitution accompanied by the dispersed House of Representatives of election result and formed the DPR-GR which members nominated by President.

In 1960, Department of Social Services held the national family welfare discussion, one of the main agenda was the discussion of marriage act, conference of Advisory Board for Marriage Development and Preservation held by Department of Religious Affairs in 1962 discussed the marriage act as well. In 1963, the National Law Development Agency and Indonesian Bachelor of Law Community made law seminar. The New Order took over the government, Provisional People's Consultative Assembly, through TAP No. 
XXVIII/MPRS/1966, especially the article 1 paragraph 3 stated that it is immediately needed to be formulated a marriage act based on Five Principles. Then, on July 31st 1973 with letter No R.02/pu/VII/II/1973, the President conveyed a script of legislative general of marriage to the chief of the House of Representatives for being discussed.

After the act no 1 of 1974 on marriage was formulated, intermarriage has changed in meaning, regarding to article 57 the Act No 51 of 1974 that the intermarriage is defined as a marriage between two people in Indonesia who are in compliance with different law because of the different nationality and one of the parties is Indonesian.

Act No 1 of 1974 on marriage does not arrange the interfaith marriage. It causes some understandings; first, the act implicitly does not allow the interfaith marriage, because it takes place a marriage to the religion itself. "that marriage is valid "if done according to the law of religion and belief of each party". There is no religion in Indonesia that allows the interfaith marriage. Second, the statement stated that the act of marriage does not arrange the interfaith marriage, thus it refers to article 6 of the act of marriage, the old regulation can be applied, the article 6 of intermarriage regulation (Regeling op Gemangde Huwe Lijkeen S. 1898 No 158). The act of marriage article 66 is:

'for marriage and all things related to marriage based on this law, then with the enactment of this law, the provisions set forth in the Book of Civil Law (BurgerlijkWetboek), Marriage Ordinant of Indonesian Christian (HuwelijkOrdonantie Christen Indonesiers S. 1933 No. 74), Intermarriage Regulation (Regeling op de GemengdeHuwelijken S. 1898 No. 158) and other regulations governing marriage to the extent provided for in this law shall be invalid'

\subsection{The Interfaith Marriage by Indonesian Council of Religious Scholars View}

The Indonesian Council of Religious Scholars issued the intermarriage rules on June $1^{\text {st }}$ 1980 as response of people's attention development through the intermarriage is done much more often. In fact, the discussion of the instruction was held in the $2^{\text {nd }}$ annual conference Indonesian Council of Religious Scholars in 1980 and not in ordinary instruction commission meeting. The instruction consists of two statements, first, an Islam woman is forbidden to marry with non-Islam man; second, a moslem man is not allowed to marry with a non-Islam woman. The instruction was signed by Hamka, as the General Chairman, Kafrawi, the General Secretary of Indonesian Council of Religious Scholars, and AlamsyahPrawiranegara as the Minister of Religious Affairs. According to AthoMudzhar, the instruction became strange because it was signed by the Minister of Religious Affairs.

The statement stated in the instructions contained the citation from Al Quran and Hadith and no one from fiqih. The first verses of $\mathrm{Al}$ Quran were the verses that clearly forbids the marriage of the believing men and women to idolaters (who do not believe in Allah), because certainly a believing slave is better than an idolater; second, a believing man can marry with people of the Book (a Christian and Jewish woman); third, forbid a believing woman with a disbeliever;fourth, to avoid their selves and their family into the hell. The cited hadith was about marriage that has completed a half of religion and the believe that children are born pure, their parents make them Jewish, Christians, or Zoroaster.

It was interesting because the intstruction forbids a marriage between a believing man and Ahl al-Kitab woman while Al Quran allows that. It is because the loss (mafsadah) is bigger than the benefit (mashlahah). The instruction was assumed radical even though it referred to the conditions in Indonesia. Moreover, it was contradictive with classical fiqih kitab referred 
by Indonesian Council of Religious Scholars usually used to make other instructions. The classical scripts allow a believing man marry with Ahl Al-Kitab woman.

\subsection{Law analysis submitting judicial review of the Act of Interfaith Marriage}

Five Indonesians that consist of students and alumni of the Faculty of Law of the University of Indonesia submitted judicial review towards the act of marriage, the Act No 1 of 1974. The Act says that marriage is legal if it is based on their religion and belief. They argued that constitutional right is loss or potentially loss by the requirement of marriage legality based on the religion. They asked Indonesia's Constitutional Court to decide the Act mentioned in their claim is contradictive with article 27 paragraph (1), article 28B paragraph (1), article 28D paragraph (1), article 28E paragraph (1), article 28E paragraph (2), article 281 paragraph (1), and article 29 paragraph (2) of the 1945 Constitution of the Republic of Indonesia because it has no legal force.

One of them, Damian Agata Yuvenus stated that his party wants to have a legal force towards civil constitutional right support, especially the right of religious freedom for marriage. As he stated that "this is the right of equality of law and the freedom of discriminative treatment". This claim was aimed to refurbish the state position in marriage law. The act review of interfaith marriage was based on social unrest of Indonesia caused by the policy. We as the litigants are not in interfaith relationship, this claim is not personal.

The judicial review of marriage acts No 1 of 1974 received some supports, such as from Andreas Hartono, a researcher from Human Right Watch (HRW), he said that the Article 2 paragraph 1 of the Act No 1 of 1974 on Marriage causes the discrimination for the interfaith mates. People who do the interfaith marriage must sacrifice their religion and faith to have a legal marriage status.

The support was also from Representative of Indonesian Buddhists (Walubi) and Council of Churches in Indonesia (CCI). Walubi tried the marriage of the same religion, however, the interfaith marriage is still tried to be held. Moreover, CCI support the interfaith marriage legalization as well. The article 2 paragraph 1 is assumed that it ignores the reality that Indonesians have various backgrounds and cultures and contravenes the human rights. This is also reaffirmed by the CCI attorney, Nixon Lalu:

"therefore, this article 2 has ignored the reality that love is universal for human, it ignores skin color, heritage, or religion. In spite of interfaith is unideal, marriage of people who are from different tribe, race, and religion is possible"

The different view was stated by Indonesian Council of Religious Scholars and the Executive Board of Nahdlatul Ulama representative asked the litigants of the article 2 paragraph (1) of the Act No 1 of 1974 on Marriage to read the historical background of this policy. The claim was submitted without unclear references and rising problems.

There was also resistance towards the judicial review of the Act No 1 of 1974 on Marriage. It was representative by legal and human rights expert staff of Ministry of Religious Affairs, Machasin, who read the details. Machasin said that he read the details representing the Ministry of Law and Human Rights Affairs and Ministry of Religious Affairs that the article was not contradictory to the 1945 Constitution. "the article 2 paragraph (1) of the marriage act is concurrent with the article 28 of the 1945 Constitution stating that there is restriction for public order to in applying duty and rights." Said Machasin in the session of Indonesia's Constitutional Court building, Medan Merdeka Barat Street, Jakarta, Tuesday (October, 14th 2014). He also conveyed that government disagree with the litigants if the article is as judgment for the human rights. The marriage registration is equal with media; it is an official 
deed as state document. Furthermore, he said," it does not need to review and accept all the President's statement and state that the article 2 paragraph 1 of the Marriage Act is not contradictory to the article 2 paragraph 1 and the article 28D paragraph 1, article 28E paragraph 1, article 28E paragraph 2, article 281 paragraph 1, and article 29 paragraph 2 of the 1945 Constitution."

Regarding to this problem, Suhadi, Ph.D., a teaching staff of Religion and Intercultural Study Program of Gadjah Mada University was invited as an expert witness for judicial review in Indonesia's Constitutional Court, on December, 4th 2014. Suhadi who researched the interfaith marriage stated four main points in his disposition, such as [5]:

The first, the rights of establishing family cannot contravene to the right of embracing their own religion and belief. The two rights notified in the Act of article 28B (1) "every person shall have the right to establish a family and to procreate based upon lawful marriage", and article 29 (2) says "The State guarantees all persons the freedom of worship, each according to his/her own religion or belief'. According to the articles, Suhadi concluded that constitution of the Republic of Indonesia should protect prospective spouse who wants to marry with different religion person and still stand on their own religion or belief.

The second, the Office of Religious Affairs and the Registration Office for Population Affairs apply the article 2 (1) of the Act no 1 of 1974 by objecting the marriage registration from prospective spouse who have different religion. Some Offices of Religious Affairs provide 'letter of undertaking' form or 'minutes of religious cross', to be used as administration documents completion of marriage registration, especially if identity card or other civil documents from prospective spouses still show different religion. This case is not only for certain religion (such as Islam), but for all religions, for instance Christian and Catholic, based upon the regulation as well (Circular Letter of Department of Home Affairs No. 477/74054 of 1978 on Guidelines of Refilling the Religion Column at appendix Ministerial Letter of Ministry of Home Affairs No 221a of 1975) shall be considered as different religion .

Next, there is emptiness of the interfaith marriage law in the Act No 1 of 1974 on Marriage. Suhadi explained that many law experts and judges argued that interfaith marriage is not defined by the Act No 1 of 1974 on Marriage. Therefore, the interfaith marriage law can refer to provision Stbl 1898 No 158 on Intermarriage.

Finally, law reformation has defined non-discriminative and legal interfaith marriage registration practices. The State published Law No 23 of 2006 on Population Administration, "Marriage is carried out between religious people" (the explanation of the article 35 letter a) "defined by Court" (the article 35) classified as "Legal marriage based upon legislative regulation" (the article 34). Based on the provision, nine interfaith marriages have law force through the District Court in Surakarta, Bogor, Malang, and Lumajang.

According to the Court, to apply the rights and duty, every person shall abide by restriction in the act aiming to guarantee the accreditation and reverence to others' rights and freedom. Additionally, it is to fulfill the justice by considering moral, religion, security, and public order in democratic public according to the Five Principles and The Constitution. The Act No 1 of 1974 has shown the principal of the Five Principles and the 1945 Constitution.

Indonesia's Constitutional Court Decree No 68/PUU-XII/2014 stated in public. It is read in Plenary Meeting of Indonesia's Constitutional Court on Thursday, June, 18th 2015 by eight judges of Indonesia's Constitutional Court. In their decision, Indonesia's Constitutional Court assessed that the litigants are under their authority and have legal domicile to file petition for reconsolidation the Act based upon the Constitution. The litigation completely does not reason legally, all and all, it is objected at all. 
Indonesia's Constitutional Court Decree is more emphasized for the religion aspect. The human rights fighters argued that interfaith marriage is a response of establishing the anthropocentric principles of pluralism, nationalism, human rights, democracy, and benefits. Furthermore, they considered interfaith marriage is ijtihad field; the marriage is more prioritize happiness and benefit principle rather than the implementation of religious value. Although, according to Indonesia's Constructional Court, Indonesia is the state which belief in One Supreme God, hence, the happiness of marriage should be based on the religious aspect.

\section{Conclusion}

The Constitutional Court in its decision Number 68 / PUU-XII / 2014 rejected all material tests submitted by the applicant. The Constitutional Court rejected the material test giving consideration that the claim of the applicant had no legal reasons. In another perspective, the consideration of the Constitutional Court rejecting judicial review is the theological aspect, marriage is not only a matter of the anthropocentric side and the effect on the legal status of marriage. Religion is the foundation, and the State has an interest in regulating marriage. The state has the role of providing protection to form a family through a legitimate marriage, marriage is not only seen from the formal aspect but must be seen from the spiritual and social aspects.

\section{Acknowledgments}

The authors express gratitude to the Dean of Sharia Faculty of State Islamic Institute of Manado who has supported and supervised to complete this article.

\section{References}

[1] Y. Baidi, "Fenomena Nikah Beda Agama di Indonesia: Telaah terhadap Putusan Mahkamah Agung Republik Indonesia No. 1400 K/Pdt/1996,” J. Sosio-Religia, vol. 9, no. 3, 2010.

[2] I. A. M. L. Dewi, "Implikasi perkawinan beda kasta dalam perspektif hukum, sosialbudaya dan religius di Banjar Brahmana Bukit, Kecamatan Bangli, Kabupaten Bangli," J. Pendidik. Kewarganegaraan Undiksha, vol. 1, no. 6, 2013.

[3] A. Pujiasih, "Pernikahan Beda Agama Menurut Islam dan Katolik," UIN Syarif Hidayatullah Jakarta, 2008.

[4] Alyasa, Abubakar, Ali, and Saifan, Perkawinan Muslim dengan Non-Muslim Dalam Peraturan Perundang-undangan, Jurispundensi dan Masyarakat. NAD: Dinas Syariat Islam Provinsi NAD, 2008.

[5] UGM, "Nikah beda agama hak untuk tak pindah keyakinan dilindungi konstitusi." . 